\title{
СТАНИСЛАВ ВИНАВЕР О СРПСКОЈ ЈЕЗИЧКОЈ СИТУАЦИЈИ С ПОЧЕТКА 19. ВЕКА
}

1. Српска авангарда и предвуковски период. Српски авангардни писци, који су се почетком 20. века појавили пре свега рушећи традицију српске модерне (Милана Ракића, Јована Дучића и других) и њених апологета (Јована Скерлића, Богдана Поповића итд.), нису показивали много интересовања за предвуковску епоху развоја српског књижевног и песничког језика. Далека језичка традиција, удаљена при томе од језика којим су стварали на различитим равнима, није се показивала као инспиративна нити као стилски резервоар при писању књижевних дела нити као повод за есејистичка и полемичка промишљања. Значајни изузеци од наведене тврдње стизали су тек после прве фазе њиховог стваралаштва, оне из међуратног периода. У њих би, несумњиво, првенствено морао бити сврстан језик Сеоба Милоша Црњанског, дубоко укорењен у рускословенској, руској и славеносрпској традицији не само на лексичком, лако видљивом, него и синтаксичком плану. Занимљив је, а широј јавности мање познат, и пример књиге Заноси и пркоси Лазе Костића, коју је Станислав Винавер дуго писао, а објављена је 1963. године.

2. Винавер и историја српског језика. Функционисање и значај рускословенског и славеносрпског језика, као и домети и ограничења Вукове реформе, сагледани су у овој монографији из перспективе појаве и развоја песничког језика Лазе Костића, романтичарског писца којег је Винавер сматрао централном српском књижевном фигуром на смени 19. и 20. века. Опис „читаве једне епохе која је лудовала за језиком, као главним обележјем божанства на земљи" (Винавер 2012a: 95), дакле, био је само полазиште и неопходан увод за сагледавање величине песничког 
и језичког експеримента Лазе Костића. То, међутим, не значи да је Винавер понудио само оквирну скицу. Напротив, на више од четрдесет страна (Винавер 2012a: 61-103), а и касније у књизи, па и у другим књигама, оцртава се детаљно политички, верски, привредни и културни живот Срба, са посебним акцентом на српску језичку ситуацију.

Лако је видљиво да се писац у опису језичких процеса на смени векова није превише удубљивао у језичку литературу. Несклон поступцима и делима централних личности лингвистичке србистике, пре свега Ђуре Даничића и Александра Белића, ${ }^{1}$ Винавер је више пажње посветио архивској грађи, приређеним препискама, оригиналним делима из српске књижевне прошлости, историјским и књижевноисторијским расправама и студијама, изостављајући из литературе чак и доступна круцијална дела из историје српског књижевног језика, попут монографије Почещи къижевног језика код Срба, коју је Борис Унбегаун објавио 1935. године на француском језику.

3. Социолингвистички приступ. И пре конституисања социолингвистике као науке, многи историчари књижевног језика имали су, и морали су имати, социолингвистички приступ при тумачењима језичких политика у прошлости. Управо такав је и доминантан Винаверов правац сагледавања. Анализирајући утицај католичке и православне цркве на развој словенских књижевних и песничких језика у прошлости, а позивајући се на Копитареву преписку и архивску грађу коју је издао Алекса Ивић, Винавер поставља једно од кључних социолингвистичких питања везаних за српску триглосију у 18. и почетком 19. века:

„Да се упитамо, са извесном неверицом: може ли се и борба противу црквене словенштине у Српству, борба за народни језик, бар донекле - везати за настојања католичке цркве? То се, одвајкада, тврдило од стране ревносних 'православаца', у доба Вуково... Ко изучава Копитара, види да је Копитар пре свега желео Србе да одвоји од њихових попова. Проблем је сложен. Није посреди, код нас, само класна ограниченост калуђера. Ето, лукава католичка црква схватила је значај народних језика баш из класних интереса. Она је увидела да мора да се послужи народним језиком - кад јој народни језик даје мисионарског успеха" (Винавер 2012а: 89-90). ${ }^{2}$

\footnotetext{
${ }^{1}$ В. Винавер 20126.

${ }^{2}$ Коначна оцена Копитаревог становишта следи нешто касније у књизи и веома је сложена. Наиме, тежиште се пребацује са верског на политички и државни план, па Винавер (2012a: 94) у том духу констатује: „Копитар је фанатичан Аустријанац, прожет мишљу: да Аустрија треба да обухвати што више Словена и тиме постане противтежа мрске му, па и варварске му Русије. Мржња Копитарева на српске калуђере има дубље корене но сви корени верски - јер је Копитар више филолог но човек вере.” Остаје отворено питање да ли је почетком 19. века било могуће овако оштро раздвајати политички, верски и научни аспект бечке језичке политике, и генерално и у Копитаревом случају.
} 
На истоме месту писац покушава да лоцира и позицију Српске православне цркве. Не занемарујући стилске потребе везане за још увек важећу престижност библијског стила у сагледавању вредности књижевног текста, Винавер (2012а: 90) ипак у први план ставља „политичке сврхе”, заборављајући да се осврне и на културолошки значај традиције коју је створила Slavia Orthodoxa:

„Наш славеносербски био је Српству наметнут од високог клира из разлога чисто политичких (али су и естетско-библијски играли извесну улогу): да би се народ осетио у што већој зависности од цркве и црквених великодостојника и да би се одржала присна политичка и културна веза са Русијом, жариштем православља. Црква је, дакле, и код нас баратала језиком у политичке сврхе.”

Наведени цитат указује на кључну теоријско-методолошку грешку у Винаверовим тумачењима, а то је поистовећивање рускословенског језика са хибридним славеносрпским језиком. Наиме, за разлику од рускословенског језика, који се у употреби са полифункционалног идиома на смени векова свео само на богослужбени, славеносрпски језик као продукт жеље за разумљивијим изразом у српској култури имао је свој видљив унутрашњи и спољашњи развој. Винавер, нажалост, није увидео да се славеносрпски језик мењао и у својој структури, пролазећи кроз континуирани процес вернакуларизације тј. посрбљавања, али и у својим функцијама, заузимајући све више простора у грађанској култури, све до његове потпуне доминације у сфери световног почетком 19. века.

4. Могућност развоја као вредносни критеријум. Као писац који је непрестано тежио новом и актуелном књижевном изразу, изразу који ће бити у складу са духом времена у којем настаје, Винавер је могућност развоја било којег језичког идиома сматрао важним фактором при вредновању. Управо из те перспективе, додајмо, он је критиковао и домете вуковског језика, сматрајући га окованим и недовољно отвореним за промене пре свега у равни прозодије, о чему ћемо писати на другом месту. Не чуди стога што је и црквенословенски језик, као идиом који јесте био у доброј мери канонизован чак и у епохи о којој пише, Винавер доживљавао као сметњу „природном развоју” и ,језичном напретку”:

„Само је код нас била несрећа што је православна црква, баш у доба народног буђења, хтела језик да задржи од природног развоја! Православна црква погрешно је прорачунала, али је она рачунала. Језични напредак и сама природа људска оборили су црквене језичке стеге у нас. Црква је била постала противник свакој култури која почива на народном језику. И готово све снаге народног језика, који је православна црква хтела не само да обузда него да деградира на ниски идиом слепачких клањалица, на псовачки жаргон баба-Смиљане и других непросвећених задушних и незадушних баба - пошле су противу саме цркве” (Винавер 2012a: 90). 
Проблему могућности развоја и напретка изражајних могућности црквенословенског језика, али и могућности да језик утиче на наш ,унутрашњи преображај” и „брзо кретање”, Винавер (2012а: 185) се вратио и касније у књизи, контрастирајући га са таквим могућностима народног и фолклорног језика: „С једне стране, имали смо помпезни, високопарни црквенословенски. Он је био спољни и свечан, готово није дејствовао на унутрашњи преображај - штавише, задржавао је живот од брзог кретања, од вртлога и струјања."

И на другоме месту, у расправи индикативног наслова ,Језичне могућности", Винавер се још једанпут осврнуо на проблем развоја књижевног и песничког језика. Могућност развоја постојећих идиома, сматрао је писац, није била велика ни у изразу предвуковаца ни у изразу вуковаца, што су условили супротни фактори. Вуковски језик на овоме се месту карактерише и као анахрон у европском контексту:

„Највећа је погрешка кад се мисли да је Вук озаконио за књижеван, један сиров и неизграђен горштачки и говедарски дијалекат. Црквенославјански, тадашњи књижевни језик, био је у ствари много неразвијенији према могућности свога развоја. Јер Вуков језик јесте сиров, али не у односу на себе сама: он је врхунац једнога стања, он је савршен израз једнога стања, он је зрео. Само је та зрелина застарела за Европу” (Винавер 2012б: 193).

5. Језичка и културна политика. Иако, дакле, у коначном збиру није превише веровао у потенцијал вуковског стандардног језика - уроњеног у српске новоштокавске дијалекте, тј. у њихове руралне говоре, као и у фолклорни коине - Винавер је бранио Вука од других, и данас постојећих, напада да је покушао покатоличити Србе. Узимајући у обзир проучавања Мите Костића, Винавер (2012а: 91) уочава поклапање Копитарових и Вукових језичких интереса, али и истиче да је „вуковаца”, тј. заступника идеје о увођењу књижевног језика са народном основом, било и пре Вука. Занимљиво је и битно да у овоме контексту Винавер нигде у уводном поглављу не спомиње ни Доситеја Обрадовића ни друге просветитеље:

„Костић је утврдио: да су се у језичком погледу поклопили интереси аустријских реформатора духовног устројства (још од Марије Терезије па надаље) и Вука и вуковаца (пре Вука и за време Вука). Сви они који су хтели да уведу народни језик у школу и књижевност - Вук и вуковци још и много пре Вука, определивши се за народни језик - хтели су, наравно, да прекину са вештачким и рогобатним црквенословенским."

Константа и доминанта бечке језичке политике према словенским православним народима у монархији прецизно је детектована и јасно формулисана, али је истакнут и један практични државни циљ идеје о увођењу народног језика у функције које су припадале рускословенском и славеносрпском језику: 
„Аустријска државна идеја (и то још од времена Марије Терезије - то је велика ствар коју наглашава Костић) прегла је да одстрани утицаје Русије у својој држави, и на томе, језичком путу. Аустрија је поглавито из тог разлога хтела да уведе народни језик у српске школе на своме подручју. (Имала је и других разлога: да дође до просвећених лаичких чиновника). Њој је Вукова реформа добродошла" (Винавер 2012a: 91).

Иако пише о подударању интереса, Винаверу је стало до јасног раздвајања коначних циљева језичке и културне политике између Аустријанаца и Срба, између Копитара и Вука. Аустријски циљ је, према Винаверовом тумачењу, била реформа државе, док је код Срба кључни био културни и духовни препород:

„Посреди је подударање интереса две иначе сасвим опречне големе и историјске снаге: Аустрија реформише државу - Срби реформишу душу. Јасно је да је православна црква беснела противу Вука и Вукових реформи" (Винавер 2012a: 91$){ }^{3}$

Описујући пропаганду коју је против Вука вршила црква, Винавер (2012a: 91) имплицитно брани Вука од напада који, иако су све ређи, не престају ни данас. Селектована лексика и фразеологија (утеривати страх у кости) сведоче да Винавер није имао пуно разумевања, а ни симпатија, за поступке цркве у турбулентном историјском периоду:

„Она није смела отворено да иступи и противу саме Аустрије и прејаснога хабзбуршкога дома. Али зато је Вука називала јавно и тајно католичким агентом, приписивала му смртни грех да хоће да поунијати Србе (да би их предао католицизму, да би народу одузео душу, која је сва у традиционалном православљу). Калуђери су утеривали страх у кости простоме народу. Вук ће да нас пошокчи!”

6. Диглосија као културни феномен. Поистовећивањем рускословенског и славеносрпског језика Винавер је замутио прецизно сагледавање српске језичке ситуације. Првобитна триглосија са рускословенским, славеносрпским и српским народним језиком у функцијама високог, средњег и ниског стила свела се, захваљујући свођењу рускословенског језика само у црквени домен, на хомогену диглосију у световној култури, са славеносрпским као вишим и народним језиком као нижим идиомом. ${ }^{4}$

\footnotetext{
${ }^{3}$ Иако је покушавао да објективно сагледа језичку ситуацију, чини се да је Винавер (2012a: 91) био престрог у оцењивању потеза Српске православне цркве јер није у потпуности сагледао веома тешку позицију православних народа, а посебно Срба, у монархији: „Из својих криво и погрешно схваћених интереса, преуско је црква гледала на те ствари: неисторијски, ненаучно и дилетантски." С друге стране, и свођење аустријских интереса само на државне, а не и верске, такође представља поједностављивање у анализи.

${ }^{4}$ Будући да се славеносрпски језик у доситејевској фази, тј. доситејевски језик, сасвим приближио народном нарочито у фонетско-фонолошкој и морфолошкој равни, границе
} 
У Винаверовој анализи, на пример, добро је одређена стилска позиција Лукијана Мушицког, „који је писао на оба 'наречја': дакле и славеносербски и српски - сматрајући да их никако не треба 'мешати' - као што су други чинили" (Винавер 2012a: 92), али је лоше схваћена његова намеpa, која је сагледана искључиво као ситношићарџијска, а не као сасвим конкретан одраз развоја класицистичких поставки културе, базираних на коегзистенцији три стила:

„Родољуб жарки, Мушицки мисли да је то врхунац богословске мудрости: 'Придобићемо Русе ако се служимо црквенословенским, који је усклађен у њиховом духу! А узгред ћемо и наш језик неговати!' А шта ћемо изгубити? Себе!!! Мушицки, дакле, не прихвата славеносербски само из политичких и верских разлога, него, као, хтео би оба језика - и српски и сербски. Само, ни то није пошло за руком никоме, а најмање Мушицком" (Винавер 2012а: 93).

Коментаришући позицију песника Мушицког, идеју о диглосији у српској култури, поставку са славеносрпским језиком у функцији вишег стила и српским народним језиком у функцији нижег, Винавер (2012а: 93) тумачи искључиво као покушај црквеног „подваљивања”: „Упитајмо се: ко коме подваљује и може ли се тако подваљивати, радити на два разбоја, на два језика?"

Винавер (2012а: 93) само наговештава, али не наглашава експлицитно, да је пропаст идеје о српској диглосији заправо последица победе романтизма, односно смене стилских формација у којој је романтизам истиснуо и класицизам и сентиментализам. У овој промени приспела је формација која је инсистирала на доминацији народног језика у свим друштвеним функцијама, односно на укидању диглосије у свим националним културама: „Копитар је хиљаду пута већи романтичар од Вука (и као такав и ближи вуковцима но Вуку). Копитар је вуковац, а не Вук копитаровац."

За разлику од многих критичара који су Вуку замерали, а и данас то чине, на конзервативним, руралним основама његове реформе, Винавер (2012a: 93), сасвим супротно, управо инсистира на грађанском елементу кључних реформаторових културолошких и лингвистичких поставки, које су биле просветитељског усмерења: „Вук је, несумњиво, желео да српски народ пође путем просвећеног грађанског успона, који је обзнањен у Викфилдском свештенику. Тај пут није ни херојски, ни феудални. Вук је грађанин."

7. „Драж славеносербског”. Потпоглавље са управо оваквим насловом у Винаверовој књизи вероватно је најинспиративније за стилистичке анализе, а истовремено сасвим лишено ауторових социолингвистичких

међу њима почетком 19. века из ове перспективе веома су условне. Сагледавање лексике и синтаксе, међутим, даје другачију слику. 
запажања. Веома је занимљива жеља авангардног писца да сагледа вредности стила славеносрпских писаца, улазећи у мотиве за њихово „високопарно каћиперство” и налазећи их пре свега у настојању да се постигне ефекат учености и топлине: „Ствар са славеносербским ипак није тако проста. Славеносербски има извесне дражи, извесна високопарна каћиперства, кад жели да буде учен и уман, и кад се потруди да буде топло и присно достојан предака, њихових подвига, њиховог благочашћа и њихове светле историје” (Винавер 2012а: 95). На примеру језика Милована Видаковића, најпопуларнијег писца епохе, Винавер на истоме месту региструје и архаизацију као наглашени стилски поступак, усаглашен са тематиком самих дела: „Милован Видаковић преведен на коректан српски (како то предлаже Павле Поповић у своме делу о писцу Усамьенога јуноше и Веселих двора Иве Загорище) изгубио би много - па можда и све. Милованова безазлена надахнута старинска језичка стилизација просто нас разоружава. Осећамо сав онај његов благородни напор: да буде стари Србин и докраја Србин."

Стилске одлике Видаковићевог језика логично су повезане и са стилском формацијом у чијим оквирима је писац стварао, а потом се сентиментализам препознаје, асоцијативним преношењем које је тешко реконструисати и мотивисати, и у преписци кнеза Милоша. Лексичке славенизме Винавер (2012a: 96) тако сасвим исправно види као централно симболичко обележје читаве стилске формације, а узроке за њихово активирање препознаје пре свега у потреби за архаизацијом, којом се, успешно или безуспешно, успоставља веза са прошлошћу и традицијом:

„Сентименталност је код њега [Милована Видаковића - прим. А. М.] у црквенословенству. Грађански паорски језик не би био сентименталан. И кнез Милош много би изгубио да му нема дугачких црквенословенских речи и обрта. Они његовој ведрој преписци са словенским 'окончанијама' дају обележје наивна господства скоројевићке сујете и страсно жуђене велелепности. Он мисли да пише као цар Душан и деспот Стефан Лазаревић, као Бодин и Немања. Па како да се одрекне 'окончанија'?'

У очувању црквенословенског језичког наслеђа Винавер је видео елемент континуираног развоја књижевног језика као оруђа националне културе. Традиција, дакле, не ремети, не укида могућност језичког развоја, континуитет не спречава еволуцију. Дисконтинуитет језичког развоја, прекид са вишевековном језичком традицијом, управо су последице Вукове реформе на којима Винавер (2012а: 96) замера великом реформатору и његовим следбеницима:

„Још нешто: народни језик, како га је увео Вук, донео је и извесне тешкоће, застоје и утуке. Лишио је Српство, на махове, језичке непрекидности са старом и благочестивом прошлошћу, са нечим високодржавним. Натерао их да живе 
и мисле готово искључиво у напрегнутом и тугаљивом садашњем времену, да мисле чулно и опипљиво у сталном praesens-y historicum-у - без неопходних, сваковрсних партиципа који се мењају, без умудрених пасивних облика, који трпе као и свака раја. Сем тога (а ту Вук није толико грешио као вуковци), стари црквени имао је извесну смелост и изграђеност у апстракцијама, у психологији греха и опроштаја - и то не само у погледу лексичког блага, већ и именичких форми."

Лако је видети да су у питању стандардне примедбе на резултате Вуковог реформаторског деловања. Неке од њих, попут тврдње да је Вук протерао партиципе из стандардног језика, србистика је временом одбацила, будући да је студија Љиљане Суботић доказала њихово сигурно повлачење и у самоме славеносрпском језику. Друге, опет, немају никакво упориште, попут тврдње о повлачењу пасивних конструкција. Tpeћe су, коначно, сасвим утемељене, попут оне о привременом осиромашењу лексичког фонда за означавање апстракција, што је овековечено у Вуковом Српском рјечнику, а о чему постоји богата литература.

8. Закључак. При крају „Предигре”, како Винавер (2012а: 7) назива уводну главу у којој даје историјски контекст појаве Лазе Костића, стоји записано: „Предигра је завршена. Српски народ треба извести из пустиње. Тражи се Мојсеј. Најпре, борба два језика и два сталежа. Подручје: Војводина, односно и читаво Српство, јер је Војводина у то доба српско културно подручје по превасходству. Језици: црквенословенски и српски. Први, славеносербски, не води никуд, па ни у прошлост. Он је вештачки докраја" (Винавер 2012а: 100). И из овога цитата, као и из претходних, опет се лако увиђа суштински Винаверов превид у сагледавању српске језичке ситуације на смени 18. и 19. века, поистовећивање, или барем недовољно дистанцирање, рускословенског и славеносрпског језика као књижевних језика са различитом прошлошћу, функцијом и позицијом у српском друштву. Славеносрпски језик, наравно, није био вештачки до краја. Овакву квалификацију би, уосталом, без резерве и прецизирања тешко било приписати и рускословенском.

У покушају да истакне и врлине и ограничености рускословенског, славеносрпског и вуковског језика, видели смо, Винавер се кретао по линији на којој су истовремено били луцидна запажања, добре синтезе, и поновљене туђе омашке, али и сопствене. Будући да се није ослањао на референтну литературу, овакве омашке су се и могле очекивати. Много је важније, међутим, нешто друго: да је један авангардни писац 1963. године, у време када су према свим облицима црквеног наслеђа у култури упућиване углавном непријатне речи и негативни судови, пажњу културне јавности скренуо и на вредности „предвуковског” књижевног наслеђа, пишући о „дражи славеносербског”. 
Тиме је ова Винаверова књига, попут књиге Меше Селимовића $3 a$ и против Вука, допринела новом научном и културном интересовању за многе заборављене и скрајнуте писце славеносрпске, што је до сада ретко истицано при набрајању Винаверових заслуга за развој српске културе.

Штета је, додајмо на самоме крају, што Винавер наносе лексичких славенизама као одразе српске књишке традиције није препознао и у делима самога Лазе Костића, чиме би се један круг отворен „Предигром” у Заносима и пркосима Лазе Костића могао затворити у закључку књиге.

\section{ИЗВОРИ}

Винавер 2012а: Станислав Винавер, Заноси и пркоси Лазе Костића, Дела Станислава Винавера, књига 5, Београд: Службени гласник.

Винавер 2012б: Станислав Винавер, Дела Станислава Винавера, књига 5, Београд: Службени гласник. 